International Information and Library Review, 31 (4), December 1999, 225-244. [ISSN 1057-2317] [online]:

http://www.sciencedirect.com/science?_ob=MImg\&_imagekey=B6WGP-45K18B9-51\&_cdi=6828\&_user $=138221 \&$ _orig=browse \&_coverDate $=12 \% 2 F 31 \% 2 F 1999 \&$ \&k $=99968$ 9995\&view $=$ c\&wchp $=$ dGLbVtzzSkWb\&md5=4f153647a1cf2c278d2ce80b1fc131f2\&ie=/sdarticle.pdf [Accessed 25 June 2006]

\title{
MANAGEMENT DEVELOPMENT FOR LIBRARIES AND INFORMATION SERVICES IN LATIN AMERICA AND THE CARIBBEAN
}

\section{Ian M. Johnson}

The Robert Gordon University, Aberdeen, Great Britain (i.m.johnson@rgu.ac.uk)

\begin{abstract}
This paper reflects on the outcomes of a project undertaken in 1997/98, and examines issues relating to the development of the managerial expertise that underpins the library and information services in Latin America and the Caribbean. It reviews the results of surveys of Schools of Librarianship and Information Sciences and a small selection of employers in the region, examining the congruence between the needs of the employers and provision by the Schools and possible explanations for an apparent mutual lack of awareness of modern management techniques. Proposals for developing management expertise include: enhancing access to indigenous professional publications and teaching materials; developing a Hispanic language distance-learning programme for library managers; improving research into the job market and skills requirements; and developing an electronic network for communication between the Schools. The role of international agencies and technical cooperation projects is assessed, and attention is drawn to the need for a more positive approach to overcoming of the issues surrounding the transfer of management know-how between different cultures.
\end{abstract}

\section{Introduction}

Over the last thirty years the International Federation of Library Associations and Institutions (IFLA), together with the International Federation for Information and Documentation (FID) and the International Council on Archives (ICA), has organised a series of regional meetings for teachers of library and information sciences (LIS) from developing countries. The aim is to overcome their relative isolation, and to underpin improvements in curricula and teaching practices. In the mid-1990s evidence began to appear that the development of advanced information and library services in Latin America and the Caribbean was being hindered by problems linked to the state of management education and management practice. For example, a study carried out in Brazil in 1995/96 examined the teaching of administration in the Schools of Librarianship, and sought to verify if this satisfied the needs of the directors of libraries and information centres. It concluded that, among other things: the subject was little discussed in the national professional literature; the importance given to the subject varies from School to School; and a consensus did not exist on the ideal curriculum (Marques, 1996). 
Following discussions between officers of the IFLA Standing Committee on Education and Training and the FID Committee on Education and Training, it was agreed to try to organise an expert workshop in Latin America to consider ways to stimulate the application of modern management techniques in library and information work. Accordingly, a joint project proposal was submitted to the UNESCO Participation Programme. The proposal for the project included a number of activities:

- a survey of current curricula covering management principles and practices in the Schools of Library and Information Science in the region

- a survey of current management problems as perceived by practitioners of library and information work

- a meeting to debate the results of the surveys and identify necessary improvements in management practice, revisions in curricula and teaching methods, and developments in continuing education programmes.

At the same time, the European Commission was inviting proposals for collaborative projects to be funded as part of its ALFA programme for academic development in Latin America (Amerique Latine - Formation Academique). ${ }^{1}$ The Robert Gordon University, School of Information and Media, led a project proposal [RELACION - Red Europea y LAtinamericana en CIencias de la informacION - European and Latin American network in Information Science] to explore the development of research links between Latin American and European partners. The initial ALFA grant facilitated visits for exploratory discussions about the project and the planned dissemination seminar. That meeting, bringing together library and information specialists from throughout Latin America and the Caribbean, took place in Valparaiso, Chile, in early April 1998. Additional financial and logistical support for the workshop were received from CONICYT (the Chilean National Council for Science and Technology), and the British Council.

This paper reviews some of the literature on the subject, summarises the results of the surveys, examines some of the factors contributing to the present situation, and considers some approaches to improving the situation that might be taken, particularly by the international agencies.

\section{Management education and training in the region}

Throughout the world, the demands on librarians' managerial abilities have grown noticeably greater and more complex in recent years. To cope with these changes, it has been argued that librarians will need to develop superior management expertise (Johnson, 1999b), and that Schools of Librarianship and Information Sciences need to develop themselves to facilitate this (Kevil, 1996). As part of the background to the project a search was undertaken on INFOBILA. ${ }^{2}$ This produced some 335 references using the outmoded term 'administracion', but only 38 citations including the more contemporary terms 'gestion' and 'gerencia'. However, it did demonstrate that there is a growing body of literature produced in the region on teaching the management of information, typified in discussions of new programmes in

\footnotetext{
${ }^{1}$ The ALFA web site was viewed on 21 November 1999 at URL - http://alfa-program.com/

${ }^{2}$ A database of abstracts of Latin American publications in the field, produced by the National University of Mexico, and searchable on its Web site, viewed on 21 November 1999 at URL http://cuib.unam.mx/infobila/index.html
} 
'Information Management' and 'Information Resources Management', with their greater emphasis on managing information technology and systems.

It was also evident that the need to include general management studies in the curriculum, and to collaborate with other disciplines when necessary, has long been recognised by teachers in the region (e.g. Ferreira, 1977). Discussions on teaching methodology amongst staff from various Brazilian library schools in the late 1970s covered approaches to teaching library administration (Polke, 1978). Interest in developing the subject is reflected in studies undertaken by Miranda (1978) that not only quantified the personnel and financing of libraries, but also examined organisational relationships. The need for improvements in teaching was highlighted by Figueiredo (1983) who, in a study evaluating reference services in the region, pointed to the need for the Schools to give more attention to teaching aspects of management such as personnel selection and training, and supervisory management.

Approaches to teaching the core subjects of contemporary management education were, however, rarely discussed, even though a sound understanding of general management principles is necessary to underpin approaches to information management. Only the School of Librarianship attached to the Instituto Profesional de Santiago de Chile appears to have offered a more general advanced management programme for librarians, a 'Post-titulo para bibliotecarios en administracion y gestion'. Nonetheless, there was evidence of the application of modern management techniques to established activities. For example, relatively novel tools of financial management, such as risk, internal rate of yield, and cost of capital opportunity, and their application to management decision making in the production of electronic information have been the subject of discussion in Mexico (Ruiz, 1993). The relevance of Total Quality Management has been discussed in the professional literature in Argentina (Suter, 1994), and at a regional conference for teachers of librarianship (Ponjuan, 1996).

\section{Surveys of Schools of Librarianship and employers}

To review the current situation, questionnaires in Spanish and/or in English were sent to institutions in 26 countries: 58 to all the Schools of Librarianship and Information Sciences known to exist in the region, and 137 to a selection of employers which included most of the major library services in the region. ${ }^{3}$

Altogether 30 completed replies were received to the questionnaire sent to the Heads of Schools. A response rate of a little over $50 \%$ to an exploratory qualitative survey may be considered satisfactory, particularly as the respondents came from 12 of the 17 countries in the region where there are known to be Schools. Although almost $40 \%$ of the replies came from Brazilian Schools, this is not significantly out of line with their representation in the region as a whole, and the completed returns appear adequate to permit authoritative comment on general characteristics of teaching about management. (Fuertes, 1998)

By the time the analysis was made, 39 completed responses to a similar questionnaire had been returned by employers. The overall response rate (28\%) was poor, but possibly

\footnotetext{
${ }^{3}$ The work of Aurelia Fuertes and Luis Herrera in translating the questionnaires into Spanish, and in undertaking the initial analysis of the responses is gratefully acknowledged. The results of the surveys outlined in this paper are presented in full in a forthcoming paper: Johnson, I.M., Fuertes Medina, A., and Herrera, L.A. Management education and training in Latin America and the Caribbean.
} 
predictably so in the context of an international survey. Moreover, some respondents perhaps did not feel that they had sufficient information as a basis for precise answers, or did not understand some questions, and some omitted answers, particularly when their opinions or perceptions were sought. Whilst these results may not permit firm conclusions to be drawn, the responses did provide some interesting insights into the issues raised. (Herrera, 1998)

\section{Background information about the Schools}

The first School of Librarianship in the region was established in 1922, in Argentina. In most countries, Schools of Librarianship were first established some 40 to 50 years ago. Despite the existence of such long-established local programmes, the absence of postgraduate programmes has resulted in a strong tradition of taking up opportunities for advanced education in North America and Britain. Today, Ecuador is the only large country in the region that appears to lack any substantial provision for professional education in this field, but quite a number of the smaller countries are still dependent on inter-regional or international provision for university-level professional education, with a marked impact on the quality of library services in some because of the lack of qualified librarians (Bertrand, 1981). These problems are equally acute in the vast rural hinterlands of the large countries, away from the capital cities where most of the Schools of Librarianship tend to be located, and a variety of approaches to resolving this problem have been tried over the last 20 years, including distance-learning methods (Medina, 1987).

The results of these investigations point to the existence of small teams of academics, not necessarily well educated in professional or managerial terms, and the limited potential of many Schools to independently develop contemporary programmes.

Several aspects of management that might be the focus of attention in the curriculum were examined to assess the extent that the Schools and the employers consider the development of related knowledge and skills necessary for the personnel of libraries and information services. In overall terms, there appeared to be little difference between the employers' needs and expectations and what the Schools seek to emphasise in their teaching. However, the lesser importance attached to some subjects suggested that the development of some relevant knowledge and skills could well be marginalised.

Libraries cannot isolate themselves from new approaches when they are introduced into an organisation, and the Schools of Librarianship and Information Sciences have a role to play in preparing students to respond appropriately. Awareness of 8 management techniques that could be included as part of a contemporary education or training in management was therefore also examined. These were drawn from a list of 16 techniques which had had been promoted over the last decade and which had been the subject of recent global research (Institute, 1996). More recent techniques were less well covered in the majority of Schools. It is particularly interesting that attention appeared to focus on the more traditional management methods and techniques. A study undertaken in the USA in the 1980s had similarly noted that the latest management theories were excluded from the LIS curriculum or touched on only minimally (Rehman, 1987). The limited attention that appears to be given by LIS teachers in Latin America and the Caribbean to the latest management techniques seems not only to confirm that little importance still appears to be attached to becoming aware of them, but also to suggest that there may be problems in making teaching about developments in management relevant to library and information services. It appears that the teachers of 
librarianship and information sciences may not quickly recognise the implications for their profession of new management techniques, or may not feel comfortable in teaching about them.

However, it is also fair to point out that the responses of employers in the region demonstrated a similar lack of widespread familiarity with some management techniques, particularly the more recently promoted approaches. The majority were aware of older management techniques such as total quality management and marketing. Those employers who were familiar with particular techniques generally felt them to be useful. The newer techniques simply appeared less well known in the region.

Although the great majority of Schools have already incorporated widely recognised and established management techniques in their curricula, the evidence is not sufficient to guarantee that they are taught in an adequate or satisfactory manner. The development of a solid management curriculum, and continually updating it and integrating it throughout the curriculum requires enthusiastic, skilled, and knowledgeable teachers. However, there was little evidence that management professionals from other University Departments play a part in the education and training of librarians, and very few LIS teachers had crossed the disciplinary boundaries by studying general management. Moreover, almost half the Schools had made no provision for teachers' continuing development in management subjects in the previous 2 years. It was clear that a number of Schools and employers in the region have recognised the need to organise in-house activities for the management development of their own staff, but few had conducted any recent, systematic analysis of training needs. This must raise concerns about whether the management training provided had been less effective than it might have been.

\section{Employer perceptions of management education and training}

The answers received from employers to a number of open questions about the main problems encountered in management development for library and information services were particularly revealing. In identifying their problems many mentioned a shortage of (appropriately trained) personnel. Whilst it is encouraging that more than half the employers judged the management education provided by the Schools of Library and Information Sciences in their country to be at least satisfactory, it must be a cause for concern that a quarter considered their local Schools to be poor in this respect at least. Several respondents claimed that the curriculum was outdated. Whilst the employers proposed a wide range of developments to address these problems in the region, they did, however, acknowledge that institutional resources appear to be decreasing in many cases, affecting the Schools' ability to pay more to attract better teachers and to provide adequate opportunities for their continual retraining.

\section{Professional isolation}

In considering what solutions to some of these problems might be viable, it is essential to try to understand the factors that have contributed to the development of the present situation. The relative isolation of the region from the mainstream of developments in libraries and information work appears a significant factor. 
Geography has imposed severe challenges on most forms of communication within the region. The continental land mass of Latin America and the Caribbean islands covers a geographic area of some 7,800 thousand square miles, about 3 times the area of the United States, or 33 times the area of the Iberian peninsula (Spain and Portugal) from where the majority of the original settlers came. Today the region has an estimated population of over 450 million people. This seems large, but compared with more than 250 million in the United States and some 50 million in Spain and Portugal, the population is clearly much more widely scattered. The general level of economic development has limited air travel both within the region and internationally, imposing constraints on face-to-face contacts, and until recently telecommunication links were poor and expensive.

The organisation of the book trade within each country has not been as well coordinated as in the industrialised countries in the Northern Hemisphere, and trade in publications in the region has not been easy either internationally (Johnson, 1976) or even within countries (Johnson, 1982). It also has to be recognised that large proportions of the educated community are not necessarily sufficiently familiar with English to make effective use of imported published material. The problems arising from the language barrier to effective use of journals from outwith the region have been well documented over the years (e.g. Baretto, 1983). One employer responding to the survey also remarked that language barriers impact on advanced study in a field in which English is the major language used in journals and published conference proceedings on leading-edge topics.

Because of these communication problems, awareness of developments has been poor, in terms of what is happening not only in the rest of the international professional community, but also within the same country and in other countries within the region. For example, a study of articles published in the 4 leading Brazilian journals between 1980 and 1985 showed that papers by foreign contributors constituted only $4.1 \%$ of the total published (Foresti and Martins, 1987). McCarthy's (1983) study of library automation in Brazil showed that information was transferred between institutions in an almost random manner. Borchardt (1977), moreover, reported that at one of the first major international conferences held in the region, Latin American participants contributed few descriptions of practices in their own countries. Moreover, the papers presented at that conference were distributed only to conference delegates, and there was no subsequent consolidated publication. The publication of conference proceedings and their distribution throughout the region still appears to remain a problem today. Financial constraints inhibit conventional print publication, and there is no documentation service comparable to the Educational Resources Information Clearinghouse (ERIC) and its centre for library and information science documents at Syracuse University.

In Argentina the absence of critical thought and energy within the library profession in the 1980s has been attributed in part to the lack of journals and other publications. However, an increase in the number of library schools, a growth in research, and the appearance of a library science abstracting journal promise to underpin future development (Sabor, 1992). The professional literature produced in the region is generally increasing rapidly. Leipziger (1976) noted that the progress of Brazilian librarianship is reflected in its expanding library literature, particularly from the mid 1960s, characterised by journals emanating from the country's flourishing library schools and the proceedings of professional associations' conferences. Although some obsolete literature was still being used in teaching in Brazil in the early 1990s, positive efforts to produce material in Portuguese in areas such as 'administration' had been implemented as a result of earlier studies (Figueiredo and Menou, 
1988), and were said to be underpinning better training and the establishment of new curricula (Figueiredo, 1991).

The growth in publishing emphasised the need to coordinate initiatives in this field not only to spread awareness of developments, but also to achieve more rational bibliographic coverage and to prevent duplication of research activities. In the late 1970s staff of the Interamerican School of Library Science in Colombia ${ }^{4}$ described an experimental information retrieval system for library and information science literature using the bibliographical resources available there (Herrera C., 1978). Projects were also initiated by the Brazilian Institute for Scientific and Technical Information (IBICT) to supplement bibliographic publications issued elsewhere in the country (Caldeira, 1981).

A Mexican study analysing publishers of librarianship periodicals in developing countries, based on data published by FID in 1982, showed that library associations accounted for 50\% or more of production in Latin America, and that Brazil was the largest single producing country in the region. However, coverage of these publications by international abstracting and indexing services was poor (Rodriguez, 1987). Subsequently, the National University of Mexico's Centre for Research in Librarianship (UNAM-CUIB) initiated the most significant step to overcome these problems. Since 1985, in collaboration with CONACYT (the Mexican National Council for Science and Technology) and partner Universities in 8 other countries, it has been developing a database of abstracts of Latin American publications in the field, which came to be known as INFOBILA. This appears likely to cover the vast majority of the 60 journals known to be published in the region (Morales, 1997).

\section{Enhancing management education and training}

As part of the survey the Schools were requested to explain how they identify the management knowledge and skills that are necessary in the education of the information professionals in their countries, and to offer some ideas on how they think that this aspect of education could become more effective. Amongst the means that the Schools use most frequently to identify and meet requirements for management education/training appear to be:

- reading specialist publications

- preparation of study materials (case studies, translations, etc.)

- encouraging teachers to raise their own qualifications to masters and/or doctoral level

- diagnostic studies and investigations of the labour market.

Although these approaches do not appear to have been wholly successful, it must be acknowledged that the introduction of new ideas into the curriculum of Schools in the region has not always taken place much later than in more advanced countries. For example, the stronger Brazilian Schools in particular have usually been able to draw on their own resources to stimulate necessary developments. Carvalho (1976), for example, described the introduction of a unit in information science in the courses of the Instituto Brasileiro de Bibliografia e Documentacao in 1976. Vieira (1990) described the implementation of an information resources management programme at the Library School of the Federal University of Minas Gerais in 1990. It seems worthwhile, therefore, to examine some possible developments that adopt approaches with which the Schools would appear to be comfortable

\footnotetext{
${ }^{4}$ Escuela Interamericana de Bibliotecologia de la Universidad de Antioquia, Medellin
} 
It has long been recognised that limited resources are available to develop the bibliographic support necessary for advanced centres for the study of information sciences, and that there is a need for a study that will analyse strengths and weaknesses of the region's indigenous material in relation to the information needs that must be satisfied (Litto, 1979). Ways in which the journals and conference papers produced in the region could be made more generally available could be usefully investigated. Most of the journals and professional conferences in the region appear to be supported by not-for-profit bodies, and it is possible that in their present form their economic base is fragile. Electronic publication on the Web may be a viable alternative to print, and needs to be investigated. Librarianship and information sciences generally are advanced technological disciplines, and thus appear a most appropriate testing ground for assessing the technical, financial and legal issues that might arise in publishing full-text versions of Hispanic language papers on the Internet.

The willingness of teachers in the region to use a variety of teaching methods was also strongly in evidence in the results of the survey. The claimed widespread use of case study material raised the question as to why that was also not more widely available throughout the region. Concerns are continually expressed that if the development of aspects of management teaching is mainly in the hands of the academics (especially the full-time teachers), it may be academically sound, but somewhat distant from the real problems of libraries and information services. This is no more a problem in Latin America than in other parts of the world, but emphasises the need for the international organisations to provide the necessary stimulus for change through encouraging and sponsoring the publication of the materials required to assist teachers in the field. Again, the potential of the Internet for disseminating awareness and distributing these materials needs to be explored.

There is no question that improving education and training for both teachers and practitioners in the region is necessary and would be beneficial for both organisations and individuals. Recent research in Britain has pointed to strong evidence that organisational and technical change is held back by lack of training, and that investment in training encourages the adoption of better practices (Chennells and Van Reenen, 1999). Farmer and Campbell (1998) have also demonstrated the link between continuing professional development and individuals' career success.

The opportunities presented by distance education methods have been accepted in principle as one means to resolve the problems of library education in the region (Maura and Williams, 1993). Many of the Schools in the region have already developed their own distance education programmes to meet the needs of scattered professional communities. The development of more advanced programmes could benefit both educators and practitioners regardless of physical location.

Elsewhere emerging technologies have been used for a number of years to deliver continuing education programmes to librarians (e.g. Brandt, 1996). Leach (1996) reviewed the extent of interest in continuing professional development for librarians and information professionals by means of computer networks, network based course materials and teleconferencing in a number of countries including Jamaica. He concluded that distance education is not entirely without problems. The main barriers were the technical infrastructure that existed at the time, and the investment needed to develop distance learning using networks. Another study, in South Africa, pointed to the typical inadequacy of library support for distance learners compared to that available to residential campus students (Grobler, 1995). 
Line (1991 to date) has provided an annual, international review of the literature of aspects of library management. The initiative of the new IFLA Section on Management and Marketing in attempting to publish an annual global bibliography of relevant publications may focus further attention on the range of material available to support the teachers (Herrera and Pereyra, 1996). General developments in Latin America have also begun to be reported in annual international reviews of the professional literature (e.g. World, 1997; Delano, 1999). The issues surrounding developing indigenous materials or translating appropriate foreign material into Hispanic languages will also need to be explored. Although copyright protection and ensuring meaningful translation are readily recognised issues, a greater challenge will be the relevance of the material. The relevance of teaching intended primarily to meet the needs of advanced, industrialised countries materials produced has been widely discussed (Tallman and Ojiambo, 1990; Conference, 1992), and the merits of materials initially produced in those countries will need to be carefully assessed before they are introduced in the region. Whether electronic distance learning is entirely appropriate to management development, other than transferring knowledge about techniques, also needs to be evaluated.

The relationship between the curriculum, the changing needs of society, and the job market for information skills has received regular attention. Personal scholarship has led to a number of studies by individual academics in the region. Ferreira (1977) described a proposal for a curriculum based on changes in the social, economic and cultural climate in Brazil in the 1970s and their resulting demands on the role of the professional librarian. Other studies have analysed students' expectations with regard to the type of library in which they would like to work and their comprehension of the relevance of courses (Polke, 1977). Some concerns have, however, been expressed in the literature that, in meeting the increasing demand for librarians, the nature of the job market's needs was not fully understood by the Schools in the region (Suaiden, 1981). Equally, the Schools in some countries have sometimes felt constrained by the conservatism of professional bodies (Miranda, 1989). The recent investigation suggested that, at the moment, there may still be some difficulty in persuading employers to articulate their needs in a way that might be helpful to the Schools in the region. Whilst the Schools appear from the results of these surveys to have correctly identified and responded to the employers' key requirements, there is an apparent divergence of views on a broader range of related topics that can only be resolved by closer and open dialogue. The reasons for this were not clear, and require further exploration. More and better research is certainly necessary to provide a convincing basis for agreement, perhaps following the guidelines advocated by Moore (1986) for UNESCO, but the initiation of the substantial research projects necessary to identify trends in the job market has been inhibited by the economic realities of the region. There appears to be a case for some international subvention to assist in remedying these shortcomings.

Dissemination of the results of job market studies has, moreover, also often been limited because of the weakness of regional publishing. More recently the partners in INFOBILA have also begun building a complementary database on research in library and information field in the region (ICBALC), which is also available on the Web. ${ }^{5}$ This appears to have the potential for development as an outlet for results of any national or individual efforts to identify the needs of the job market and to spread awareness of relevant research techniques.

\footnotetext{
${ }^{5}$ Viewed on the Web on 21 November 1999 at URL - http://132.248.72.221/inv_lat/icbalc.html
} 
For this to succeed, an effective document delivery service also needs to be developed, perhaps taking advantage of the new electronic media.

In planning and executing this project, the need to improve communication between the Schools in the region was clearly identified as requiring further consideration and action if teaching and research in the field are to be based on best practice, and if professional practice in the region is to be rapidly strengthened to support its transition to an 'Information Society'. During 1989 Dosa and Katzer (1991) carried out a feasibility study for UNESCO for what was intended to be a 4-year pilot project utilising an electronic network to connect information science programmes in developing countries, and identified the potential benefits and problems of the network. The ultimate goal of the proposed project was to support educational innovation through increased cooperation among developing countries. UNESCO subsequently began an experiment with the Internet as a means of enhancing mutual support amongst Schools of Librarianship and Information Sciences on a global basis, and 3 Schools from the region (from Brazil, Jamaica, and Venezuela) were invited to participate in its SLISNET project. ${ }^{6}$ That initiative appears to have faltered, partly because of linguistic and cultural barriers (Johnson, 1997a), and partly through the declining emphasis that UNESCO Headquarters has placed on education for librarianship and information sciences in recent years (Johnson, 1998b). It is not known how many of the Schools in the region have access to the Internet, but most appear to have the potential for at least some rudimentary access. The viability of a regional SLISNET, in terms of technical infrastructure, linguistic barriers, etc. could usefully be explored.

\section{Cooperation and technical assistance projects}

It seems clear that many of the Schools will not be able to initiate developments such as those outlined without external assistance. One employer's response to the survey did indeed note the lack of support of international institutions, but without specifying what support was needed, and from which organisations. The commitment of the NGOs was the starting point for this project, and it is useful to reflect on the past and potential future contribution of national and international governmental and Non-Governmental Organisations.

A major effort to build professional education within the region has been made by the UNESCO and its regional office. UNESCO has made significant assistance available to develop Schools in, for example, Jamaica (Collings, 1973), Venezuela (Paez, 1991), Costa Rica (Galvez, 1996), and Cuba (Lopez and Ramos, 1998). A Regional University Centre for New Information Technology for training and the creation of information products and services for MERCOSUR, the economic alliance of the southernmost states in the region, is planned to be established in Montevideo, Uruguay. The creation of this Centre, which will draw on the experience of the University of Colima in Mexico, is expected to be initially supported through the UNESCO Participation Programme. UNESCO's current resources are limited, and proposals for a regional UNESCO Chair in New Information Technologies depend on obtaining funds from some other agency. ${ }^{7}$

\footnotetext{
${ }^{6}$ The SLISNET Web site was viewed on 21 November 1999 at URL - http://enssibhp.enssib.fr/SLISNET/

${ }^{7}$ For further information, visit the Web site of the UNESCO Observatory on the Information Society viewed on 21 January 2000 at URL - http://www.unesco.org/webworld/observatory/index.shtml
} 
Given the preponderance of Spanish and Portuguese speakers in the region, it might have been expected that the natural affinity with those European countries would have resulted in significant professional interchange to address these problems. It was, however, the case that in both those countries library and information services and related professional education were equally under-developed until the last decade. Spain, for example, appears to have had only 4 or 5 LIS Schools prior to 1991, and as recently as the early 1980s the training of librarians in Argentina was being examined as one possible model for reorganising librarianship education in Catalonia, Spain (Cattivello, 1983). However, significant expansion was encouraged by the Spanish government in the 1990s, as Spain prospered within the European Union and the Union focused attention on the emerging 'Information Society'. Today the subject is taught in 17 Spanish Universities, but it is probably fair to suggest that many of the staff teaching these new courses lack experience, and are still likely to be largely pre-occupied with mastering their new programmes of study. Nonetheless, the Spanish Schools are active in the region under the auspices of the Ibero-American cooperation programme. Recently, for example, the LIS School in the University of Murcia has been assisting the University of Havana to develop the UNESCO-sponsored Masters degree in Information Management (Johnson, 1997b). The University of Murcia has also been involved in a proposal to attract ALFA funds, but this has not yet come to fruition.

The presence and influence in the region of LIS educators from the United States was noted as early as the 1920s (Mueller, 1985; Souza, 1993), but some American solutions to the region's information problems have been recognised as inappropriate because they did not take into account differing cultural, social, and economic conditions (Goldstein, 1982), and curricular revisions to eliminate excessive influence of US theory have been put in train (Cesarino and Vianna, 1990). Several British and Canadian Schools have also been active in assisting colleagues in the region. The College of Librarianship Wales was closely associated with the development of the programmes in the University of the West Indies for a period in the 1970s, supported by UNESCO, and in the Pontificia Universidad Catolica del Peru in the 1980s, supported by the British Council. Following an international conference in Jamaica, in 1972, the University of Western Ontario also took part in a cooperative project with the University of the West Indies, funded by the Organization of American States and the Canadian International Development Agency (McGee, 1981). Typically, however, most such technical cooperation programmes are short-term, and there is no certainty that they will create the expertise and will to sustain continuing development.

Brazil and Argentina appear the only countries that have national associations of Schools of Librarianship to promote cooperative efforts at a national level. Occasional regional meetings have been hosted by strong individual organisations such as the Universidad Nacional Autonoma de Mexico, and sub-regional meetings have been held within the framework of CONOSUR, the Association of Librarians' Schools of the Southern Cone, based in Uruguay. The nature of the training and continuing education needs in the small Caribbean island communities has also attracted the attention of the Commonwealth Library Association (Harrison, 1977). One regional association of LIS Schools, ALECBI, the Latin American Association of Librarianship and Information Science Schools, appears to have enjoyed only a short life. More recently, the UNESCO regional office has provided assistance for a series of conferences of library science educators, the first of which was held at the University of Puerto Rico in San Juan in November 1993 with representatives from 12 continental Latin American countries, plus Puerto Rico, Spain and the US (Maura and Williams, 1993). Subsequent meetings have been held in Mexico (1996), Puerto Rico (1997), and Venezuela (1998). A new regional association, EDIBCIC - asociación de EDucacion e Investigacion en 
Bibliotecologia, archivologia, y Ciencia de la informacion y documentacion de Iberoamerica y el Caribe was proposed during the 3rd Conference of teachers and researchers in Librarianship, Archive Studies and Information Science in Latin America and the Caribbean, in 1997, and formally established the following year in Maracaibo.

\section{Concluding observations}

One participant in that conference observed that linguistic, cultural, and financial barriers still appear to inhibit the effective adoption and adaptation of ideas and methods both from within and from outwith the region, and the identification and implementation of appropriate curricular developments (Johnson, 1999a). In their study of the feasibility of using communication networks to assist Schools in developing countries, Dosa and Katzer (1991) had also noted the need for further research into the "factors affecting successful innovations by information sciences schools". Although the need for policies and processes appropriate to the needs of developing countries is increasingly acknowledged, these issues arise time and again in discussions of LIS development, and often seem to be accepted in a fatalistic manner as an almost intractable problem. Although there have clearly been efforts by teachers in the region to focus their teaching on local needs in terms of both content and style, there appears little evidence of conscious efforts by external agencies to formally adapt LIS programmes to the local context and culture whilst implementing technical assistance projects. .

Little attention appears to have been given to the fact that librarianship and information sciences draw heavily on other disciplines, that it seems unlikely that those other disciplines have been unaffected by similar challenges, and that it might be useful to examine their approaches and experiences. In fact, studies of technology transfer to developing countries have proliferated in recent years, and there have also been attempts to understand the international transfer of management know-how, although these are perhaps less well known. There is, however, a body of literature emerging on the issues surrounding the implementation in developing countries of management development processes in which the objectives, techniques, content and outcomes stem are derived from the context and values of advanced industrialised countries (e.g. Saeed, 1986). A number have examined management practices in Latin America. Estafen (1966), for example, focused on the transferability of American management practices into the Chilean business environment, and found some differences but also extensive similarities. Attention is also turning, at least in the industrialised countries, to understanding the motivation and orientation of the teachers of management (e.g. Danieli and Thomas, 1999), and to understanding the innovation process. Efforts are also focusing on systematising the development of educational multimedia in a way that takes account of different cultural and terminological concepts (e.g. Gaede, 2000), for which there appear to be well-established guidelines based on expertise in communication (e.g. Winters, 1996). These approaches clearly need to be better understood within the LIS community if transferring management development know-how from the industrialised countries into the Schools of Librarianship and Information Sciences and the practitioner community in Latin America, or indeed any other region, is to be wholly successful. The implementation of approaches such as these would clearly facilitate potential solutions to the problems encountered in the effective transfer of LIS know-how, and enable long-standing linguistic and cultural barriers to be removed. Further investigation might also reveal approaches that could stimulate initiative and innovation, and make a further contribution to progress. 
The participants in the international workshop assembled to debate the results of the surveys made a number of recommendations addressed to individuals, library managers, and Schools of Librarianship and Information Sciences in the region, as well as to the international professional associations and UNESCO (Johnson, 1998a). Their wide range of experience gave them an implicit appreciation of most of the issues discussed in this paper. The thrust of their recommendations places a significant emphasis on self-help by the professionals in the regions. They appear to have taken the view that, while the assistance of the international agencies may be needed because of their access to financial resources and know-how, it is the potential within the region that has to be drawn out effectively if desired developments are to succeed. However, it seems clear that, as well as improving support mechanisms such as network communications and access to professional literature, another pre-cursor to the preparation of the distance learning materials that appear necessary must be for the international agencies concerned to learn more about how management know-how can be most effectively transferred and embedded.

${ }^{\circ}$ The author, January 2000

\section{AUTHOR}

Ian Johnson is Head of the School of Information and Media at The Robert Gordon University, Aberdeen, Scotland. He was Chairman of the International Federation of Library Associations and Institutions' (IFLA) Section on Education and Training from 1991 to 1993, and Chairman of the Professional Board of IFLA from 1993 to 1995. He is currently Chairman of the Executive Board of EUCLID: the European Association for Library and Information Education and Research.

\section{REFERENCES}

Barretto, C.M.W. (1983) Problematica da realizacao de pesquisa pelos professores de biblioteconomia. [The problem of the research achievement of library science professors.] Revista de Biblioteconomia de Brasilia, 11 (1), January-June, 1-18

Bertrand, J.W. (1981) Plea for a reorganization of Haitian libraries. UNESCO Journal of Information Science, Librarianship and Archives Administration, 3 (2), April-June, 117-124

Borchardt, D.H. (1977) Information and development: report on the 38th FID Congress, held in Mexico City, 27 September to 1 October, 1976. Australian Academic and Research Libraries, 8 (1), March, 8-11

Brandt, K.A. and others. (1996) Current topics in health sciences librarianship: a pilot program for networked based lifelong learning. Bulletin of the Medical Library Association, 84 (4), October, 515 -523

Caldeira, P. d T. (1981) O controle bibliografico na area da biblioteconomia no Brasil [Bibliographic control in the field of library science in Brazil] Revista de Biblioteconomia de Brasilia, 9 (2), July-December, 77-88 Carvalho, M.B.de. (1976) Planejamento de uma unidade didatica em ciencia da informacao. [Plan of a didactic unit in information science.] Revista da Escola Biblioteconomia da UFMG, 5 (1), March, 72-92

Cattivello, E. (1983) La formacio de bibliotecaris arreu del mon: Argentina [The training of librarians around the world: Argentina.] Butletti de l'Associacio de Bibliotecaris de Catalunya, (3), January-June, 7-11

Cesarino, M.A. da N. and Vianna, M.M. (1990) O curso de graduacao em Biblioteconomia da UFMG. [The undergraduate librarianship course at UFMG Library school.] Revista da Escola Biblioteconomia da UFMG, 19 (special), March, 37-67

Chennells, L., and Van Reenen, J. (1999) Has technology hurt less skilled workers? An econometric survey of the effects of technical change on the structure of pay and jobs. London: Institute for Fiscal Studies. Working 
paper W99/27. Viewed on the Web on 02 October 2008 at URL -

http://www.ifs.org.uk/research/workingpapers/index.shtml

Collings, D. (1973) University of the West Indies Library School: progress report, 1971/72. Jamaica Library

Association Bulletin, January, 30-37

Conference on education of overseas students in U.K. educational institutions, London, 25-26 March 1992.

Education for information, 10 (4), December 1992, Special issue

Danieli, A. and Thomas, A.B. (1999) What about the workers? Studying the work of management educators and their orientations to management education. Management Learning, 30 (4), December, 449-471.

Delano, M. (1999) Libraries and information in Latin America in Librarianship and Information Work Worldwide 1999, edited by M. Line, and others. London, Melbourne: Bowker Saur. pp. 267-290

Dosa, M. and Katzer, J. (1991) Electronic networking in support of South-to-South cooperation. Journal of Education for Library and Information Science, 32 (1/2), Summer/Fall, 84-96

Estafen, B. (1966) The comparative management of firms in Chile. Indiana University, Division of Research. Farmer, J.C., and Campbell, F.C.B. (1998) Continuing Professional Development and career success.

Aberdeen: The Robert Gordon University. British Library Research and Innovation Centre report.

Ferreira, M.L.A.G. and others. (1977) Curriculo minimo de biblioteconomia. [Minimum curriculum for librarianship.] Revista da Escola Biblioteconomia da UFMG, 6 (1), March, 92-99

Figueiredo, N.M.d. (1983) Recomendacoes praticas para o aperfeicoamento do servico de referencia/informacao nas bibliotecas brasileiras. [Practical recommendations for the improvement of the reference/information service in Brazilian libraries.] Revista de Biblioteconomia de Brasilia, 11 (1), JanuaryJune, 35-44

Figueiredo, N., and Menou, M. (1988) Metologia para avaliacao de material didatico da area de Biblioteconomia e Ciencia da Informacao a nivel de graduacao. [Methodology for the evaluation of recommended bibliography in library science syllabuses.] Revista de Biblioteconimia de Brasilia, 16 (1), January-June, 33-44

Figueiredo, N.M.d. (1991) Relexoes em torno da formacao e da educacao continuada do profissional bibliotecario. [Reflections on development and continuing education of professional librarians.] Revista da Escola de Biblioteconomia UFMG, 20 (2), July-December, 161-75

Foresti, N.A.B., and Martins, M.S.M. (1987) Revistas Brasileiras de Biblioteconomia, Documentacao e Ciencia da Informacao: produtividade de autores no periodo de 1980 a 1985. [Brazilian library science, documentation and information science journals: productivity of authors in the period 1980 to 1985.] Revista da Escola Biblioteconomia da UFMG, 16 (1), March, 54-71

Fuertes Medina, A. (1998) Encuesta sobre la educacion en gestion en las escuelas de bibliotecologia y ciencia de la informacion de la region. [Survey on management education in the Schools of Librarianship and Information Science in the region.] Paper presented at the Joint IFLA/FID Workshop on Management and use of human resources in library and information work in Latin America, Valparaiso, Chile, 6 - 9 April 1998. Unpublished typescript. 14pp., plus 13 pp. of tables and diagrams

Gaede, B. (2000) Courseware and user interfaces across cultural borders (Courseware variants: content and user interfaces to provide information access for almost everybody) in Access 2000: intellectual property vs the right to knowledge? proceedings of the 8th international BOBCATSSS symposium on library and information science, Jagiellonian University, Krakow, Poland, January 24 - 26, 2000. Copenhagen, Denmark: Royal School of Library and Information Science. pp. 161-172

Galvez, V.M. (1996) Desarrollo historico de la Escuela de Bibliotecologia y Ciencias de la Informacion de la Universidad de Costa Rica. [Historical development of the School of Library and Information Science at the University of Costa Rica.] Revista AIBDA, 16 (2), July-December, 184-96

Goldstein, E. (1982) Tranferability of American library and information science education to Mexico. in Information interaction: proceedings of the 45th ASIS Annual Meeting, Columbus, Ohio, 17-21 October 1982; edited by A.E. Petrarca, C.I. Taylor and R.S. Kohn. White Plains, New York, Knowledge Industry Publications, Inc. pp. 116-118

Grobler, L.M. (1995) Information support to distance postgraduate students at the Graduate School of Business Leadership, University of South Africa. In Proceedings, Seventh Off Campus Library Services Conference, San Diego, California, October 25-27, 1995. Mount Pleasant, Michigan: Central Michigan University. pp. 163 174.

Harrison, K.C. (1977) Towards regionalization. Library Association Record, 79 (1), January, 20-21 Herrera, L.A. and Pereyra, R.R. (1997) Review of the management literature, 1996. IFLA Journal, 23 (5/6), 371-380

Herrera, L.A. (1998) Resultados de la encuesta dirigida a los empleadores de bibliotecas y servicios de informacion. [Results of a survey directed to employers in libraries and information services.] Paper presented 
at the Joint IFLA/FID Workshop on Management and use of human resources in library and information work in Latin America, Valparaiso, Chile, 6 - 9 April 1998. Unpublished typescript. 7pp.

Herrera C., O. and others. (1978) Un sistema de recuperacion de informacion en bibliotecologia y ciencias de la informacion. [A system of retrieving information in library and information science.] Revista Interamericana de Bibliotecologia, 1 (3), September-December, 25-41

Institute of Management and Bain \& Company. (1996) Managing the management tools. 1996. London: Institute of Management. Reported in "Dipping into the global managers' toolkit". Professional Manager, November, 30.

Johnson, I.M. (1983) Report of a visit to Venezuela. ACOLAM Newsletter (Standing Conference of National and University Libraries, Advisory Committee on Latin American Materials), (3/4), June 1982 - June 1983, 6-7 Johnson, I.M. (1997a) SLISNET - UNESCO's experiment in virtual networking between Schools of Librarianship and Information Sciences. The New Review of Information Networking, 3, 185- 201

Johnson, I.M. (1997b) Progress in education for librarianship and information management in Cuba. Focus on international and comparative librarianship, 28 (3), 31st December, 165-167.

Johnson, I.M. (1998a) Workshop on the management and use of human resources in library and information work in Latin America, Valparaiso, Chile, 6 - 9 April 1998. FID Bulletin for Information \& Communication, 48 (2), March/April, 54-59 (reprinted in IFLA Journal, 25 (1), 1999, 42-46)

Johnson, I.M. (1998b) UNESCO and human resource development for the 'Information Society'. Education for Information, 16 (3), September, 237 - 242.

Johnson, I.M. (1999a) New paradigms for professional education in Latin America? Journal of Education for Library and Information Science, 40 (2), Spring, 114 - 117

Johnson, I.M. (1999b) Catching the tide: environmental pressures for an emphasis on management in the library and information sciences curriculum. Library Management, 20 (6), 1999, 317-332

Johnson, P.T. (1976) A brief overview of the book trade in Spanish speaking Latin America in Seminar on the Acquisition of Latin American Library Materials (19, 1974, Austin, Texas). Final report and working papers. Amherst, Mass.: SALALM Secretariat. pp. 55-59

Kevil, L.H. (1996) Continuing education and the reinvention of the library school. Journal of Education for Library and Information Science, 37, (2), Spring, 184 - 190

Leach, K. and others. (1996) The use of information networking for continuing professional development. London: British Library, Research and Development Department. BLRD Report 6229, 85p.

Leipziger, F.T. (1976) Brazilian library literature. International Library Review, 8 (4), October, 379-395 Line, M.B., and others; editors. (1991 to date) Librarianship and information work worldwide: an annual survey London: Bowker-Saur.

Litto, I.M.F. (1979) Libraries for graduate education in information sciences: the bibliographic problem. (c/o Rua Padre Joao Manuel 758, Apt 83, 01411 Sao Paulo, Brazil.) Discontinued PhD, Loughborough University, UK. (Noted in RADIALS)

Lopez, M.T.H. and Ramos, L.G. (1998) Formacion academica de profesionales para la gerencia de recursos de informacion: Analisis de experiencias docents. [Academic training of professionals for the management of information resources: Analysis of teaching experience.] Ciencias de la Informacion, 29 (2), June, 33-41

Marques de Oliveira, S. (1996) O ensino de administracao nas escolas de biblioteconomia no Brasil : correlacao entre o curriculo e a literatura da area. [Teaching administration in Schools of Librarianship in Brazil: the correlation between the curriculum and literature in the field.] Campinas, Brazil: Departamento de Pos-Graduacao em Biblioteconomia, Pontificia Universidade Catolica de Campinas. Unpublished typescript. 24 pp.

Maura, M.A., and Williams, R.V. (1993) Conference on library education in Latin America. Third World Libraries, 4 (1), Fall, 49-62

McCarthy, C.M. (1983) Problems of library and information system automation in Brazil. Journal of Information Science, 7 (4-5), December, 149-158

McGee, W.H.J. (1981) Canada-West Indies: a co-operative venture in library education. Canadian Library Journal, 38 (3), June, 151-152

Medina, M.E. (1987) Ciencia de la informacion y la documentacion del programa de diseno curricular en la modalidad de educacion abierta y a distancia. [Information science and documentation in the programme of curriculum design based on open and distance learning.] Revista Interamericana de Bibliotecologia, 10 (2), July-December, 45-87

Miranda, A. (1978) Bibliotecas dos cursos de pos-graduacao em educacao no Brasil: estudo comparado. [A comparative study of libraries for post-graduate courses in education in Brazil.] 1977. Brasilia:

MEC/DAU/CAPES, 94p. Summarised as: Postgraduate education libraries in Brazil: a comparative study. Focus on International \& Comparative Librarianship, 9 (2), 15-17 
Miranda, A.L. Carvalho de. (1989) The role of professionalism in curriculum development for information personnel: the case of Brazil. in JOHNSON, I.M. Editor. Harmonisation of education and training programmes for library, information and archival personnel: proceedings of an international colloquium, London, August 9 15, 1987. Munich: K.G. Saur. (2 vols.) Vol. 2; pp.236-251

Moore, N. (1986) Guidelines for conducting information manpower surveys. Paris: UNESCO. ref. PGI86/WS/3

Morales Campos, E. (1997) Latin America and the Caribbean in A. Large, ed. World Information Report 1997/98. Paris: UNESCO Publishing. pp.107-123. (Table 2, p. 120)

Mueller, S.P.M. (1985) O ensino de biblioteconomia no Brasil. [The teaching of librarianship in Brazil.]

Ciencia da Informacao, 14 (1), January/June, 3-15

Paez-Urdaneta, I. (1991) The development of the RGPIS at Simon Bolivar University: learnings and perspectives. Journal of Education for Library and Information Science, 32 (1/2), Summer/Fall, 61-68 Polke, A.M.A. and others. (1977) Analise do corpo discente da Escola Biblioteconomia da Universidade Federal de Minas Gerais. [School of Library Science, Federal University of Minas Gerais: students analysis.] Revista da Escola Biblioteconomia da UFMG, 6(2), September, 223-245.

Polke, A.M.A. (1978) Relatorio dos seminarios do curso de metodologia do ensino em biblioteconomia. [Report of seminars held during the course on teaching methodology in librarianship.] Revista da Escola Biblioteconomia da UFMG, 7 (1), March, 149-200

Ponjuan Dante, G. (1996) La gestion de la calidad total en la educacion bibliotecologica. [Total Quality Management in teaching librarianship.] Presented at: Encuentro de Educadores e Investigadores de Bibliotecologia, Archivologia y Ciencia de la Informacion de Iberoamerica y el Caribe \#3, 1996, Puerto Rico). Documento de trabajo D presentaciones especiales num.2a. Recinto de Rio Piedras: Universidad de Puerto Rico, Escuela Graduada de Bibliotecologia y Ciencia de la Informacion. Unpublished typescript.

Rehman, S. ur (1987) Management theory and library education. New York: Greenwood Press. p.117 Rodriguez Gallardo, A. (1987) Las publicaciones periodicas de bibliotecologia en los paises en desarrollo. [Librarianship periodicals in developing countries.] Investigacion Bibliotecologica: archivinomia, bibliotecologia e informacion, 1 (2), January-June, 3-14

Ruiz Rodriguez, M. and others. (1993) Gerencia financiera para los productos y servicios de informacion electronica [Financial management for electronic information products and services] in Congreso Norte-Sur de Informacion, ONLINE 93: sistemas, redes y tecnologia. Memorias (1, 1993, Mexico). Cruz Ramos, R., and Zetter Leal, J., comp. Mexico: UNAM, CICH, Learned Information. pp. 464-468

Sabor, J.E. (1992) The issue of librarianship in Argentina. Third World Libraries, 3 (1), Fall, 40-46

Saeed, S.M. (1986) Managerial challenges in the Third World. New York: Praeger.

Souza, F.d.C.d. (1993) Ensino de biblioteconomia no Brasil: o modelo Norte-Americao. [Library science teaching in Brasil: a North-American model.] Informacao \& Sociedade: Estudos, 3 (1), 21-5

Suter, T. (1994) Calidad total y TQM en servicios de informacion. [Total quality and TQM in information services.] Grebyd Noticias, 5 (2-3), 2-9

Suaiden, E.J. (1981) Mercado de trabalho. [The job market.] Revista Brasileira de Biblioteconomia e Documentacao, 14 (3-4), July-December, 153-159

Tallman, J.I. and Ojiambo, J.B. editors. (1990) Translating an international education to a national environment: papers presented at the international doctoral student conference sponsored by the Doctoral Guild at the University of Pittsburgh School of Library and Information Science, September 23-25, 1988. Metuchen, N.J. and London: Scarecrow Press.

Vieira, A. da S. (1990) Berencia de Recursos Informacionais: o advento do futuro? [Information resources management: anticipating the future?] Revista da Escola Biblioteconomia da UFMG, 19 (2), September, 159170

Winters, E. (1994) Eleven commandments of localization. Active Voice (Society for Technical

Communication), June 1994; republished 1996 by International Interactive Communications Society. Viewed on the Web on 25 January, 2000 at URL - http://www.bena.com/ewinters/local.html

World Information (and Communication) Report. (1997 to date) Paris: UNESCO Publishing. 